\title{
DISCOURSE ANALYSIS OF DICTION USED IN "KUE DADING MANG OLEH"
}

\author{
Almizan $^{1}$, Didin Nuruddin Hidayat ${ }^{2}$, Alek $^{3}$ \\ ${ }^{1,2,3}$ UIN Syarif Hidayatullah Jakarta \\ Email : almizanzulkarnaen@gmail.com
}

\begin{abstract}
The background of this research comes from the viral post of Mang Oleh's homemade named Odading cake. Wellknown uniquely reviewed by a man named Ade Londok. Previously, it was well-known that Ade Londok was promoting a typical Bandung home made cake called Odading in an amusing manner. He promoted Odading with his mixed accents, between Sundanese and Indonesian. He also slips in a tickling rhyme so that it makes his figure interesting to be viral. In some of his social media uploads, he often promotes food with unique styles and several rhymes that invite laughter. The aim of this study is to classify which one of Keraf theories (1984) about diction that relate to Ade Londok's diction used. This study used a qualitative method in which data collection was based on literature review, video, and transcript of Ade Londok words. The study found that Ade Londok used Abstract word, Special word, Popular word, and Jargon. The controversial diction that is used by Ade Londok is not only interesting and unusual but also amusing so that influenced people to buy odading cake. His entertaining figure with his unusual review style made this man from the city of Bandung go viral.
\end{abstract}

Keywords : diction, discourse analysis, linguistics

\section{INTRODUCTION}

The term "discourse" is used within the broad study of Critical Discourse Analysis (Fairclough, 1999; El-Sharkawy, 2016). Categorical case in point of communication in the metier of lyric is of titled discuss nevertheless "meaningful symbolical behaviorism is $\mathrm{d}$ wide outlined (Bloommaert, 2005; Johnstone, 2018). Johnstone (2018) cited "discourse" therein feel shaped as a deal noun. Gee (2014) highlights in dissimilar insight of Critical Discourse Analysis. Gee (2014) pointed out the study of language at use is Critical Discourse Analysis. It is not only to say items but also to-do items. It is a study of the senses that we give lyrics and our actions when we use lyrics in a particular structure. Critical Discourse Analysisis also known outlined as the cognate of lyric supra the level of a time the judgements combine to create pregnant coherence, and accomplish objects.

Nevertheless as cited by Gee and Handford (2012), even a single time or vocalization buoy be analyzed as a "communication" or as an "action," and not fair as a sentence constitution whose "literal pregnant streams from the nature of grammar. Grammar differentiates us what "I judge you man and mate word for word substances but not when and where it indeed substances you are matrimonial. A Critical Discourse Analysis (CDA) carries the critical custom of societal psychoanalysis into most lyric studies and gives to decisive societal psychoanalysis a special focus on discourse and relationships between discuss and over-the-counter societal components (power relationships beliefs formings societal indistinguishability so forth). Moreover, decisive societal 
psychoanalysis buoy be understood as a normative and explanatory review. It is prescriptive review therein does not but account existing actualities but also values them, assesses the size to which they cope with up to various values, which are captivated (more or less contentiously) to be fundamental for just or decent fellowships (e. g. sealed criteria - real but also governmental and ethnic - of human well-being). Text philologies is a close associated study. The essential distinction between discuss psychoanalysis and text philologies is that the discuss psychoanalysis directly tells socio-mental characteristics of a person/person soon text constitution. As cited by Hendy and Tator (2002) "discuss is how lyric is victimised socially to communicate large-minded factual senses". Advance he said, lyric identified by the societal weathers of its employ by who that employ it and what form of the weathers lyric buoy never be 'neutral' as it connects our personal and social earths by Widdowson (2000). Critical Discourse Analysisis the uncovering of implicit beliefs in text. Gee $(2010,2011)$ cited that when we indeed or wrote a sentence, it has a situated condition. Set senses are reinforced as of a especial lyric shapes issue on a particular or set senses in different and specific employ structures (Gee, 2010, 2011).

Based on the explanation from the authorities, psychoanalysis is the cognate of lyric in use which the object of Critical Discourse Analysis (discourse, handwriting discussion communicatory case) are variously outlined in names of consistent progressions of sentences, proposals word or turns-at-talk. Enunciation, in its original or primary pregnant refers to allude to writers' or speakers' typical dictionary selections and way of expression. A choice of words or diction protects which delineation of rows is victimised to channel an estimate how to manakin a grouping of rows which is precise or to use appropriate verbalizations and which dash is the best to use in proper and particular spot. Enunciation is the option and use of rows, dash, or ways of speechmaking and handwriting (Hornby, 1974).

What is more, Keraf (2001) stated that there are three chief conclusions as to the enunciation, the first enunciation incorporates a sense almost which chat victimised in conveying a thought, how to agglomerate the compensate rows and use the right verbalizations and what the best dash to use in that spot, the second enunciation is the ability or skill in groping the right manakin in adaptableness of spot and ethical motive beingness achieved by club and hearer/listener, third, the right and suitable chat option is only achieved by having a big numerals of memorizing vocabularies. Patch dictionary substances that an entire chat beingness had a lyric.

The present study aims to see the kind of diction that was used by Ade Londok in his speech toward the promotion of Odading homemade cake. His words and attitudes towards diction used can be elaborated. As what mentioned before that CDA is a technique that makes a vigorous evaluation of what is supposed to be represented and explained by words. Other studies show how CDA can be used in explaining further meaning beyond the discourse itself are as follows:

The first study in line with study related to the speech act analysis was conducted by Irfariati (2017), Diction in Agus Harimurti Yudhoyono's Rhetoric as the Governor Candidate of Special Capital Region of Jakarta. The study used Keraf theory. It showed that exposure speeches of vision, mission, and flagship programs of Agus Harimurti Yudhoyono as a candidate for Governor of Jakarta used connotation diction, denotation diction, scientific diction, popular diction, special diction, general diction, abstract diction, concrete diction, and jargon diction. The second study was still conducted by Irfariati (2013) Diksi dalam Retorika Anas Urbaningrum. The study used qualitative research method using discourse analysis. The research findings of the study showed that the speech delivered by Anas Urbaningrum as announcing his resignation as the chairman of Demokrat Party contains connotation, denotation, scientific, popular, special, general, abstract and concrete diction. The similarity among those studies and the present study that they use the same method of CDA and all of the discourse analyzed has relation to Diction. The differences among these previous studies are the focus of the analysis. Overall, they use CDA to analyze the meanings and interpretation beyond the discourses. Despite the revelation found from 
the analysis mentioned, it is not necessarily the absolute fact of what the discourses represent. There is more than what each research found.

\section{METHOD}

This study was conducted using a descriptive qualitative analysis in order to analyze the type of diction (Ary, Jacobs, \& Razavie, 2002). The data was collected based on literature review, video, and transcript of Ade Londok to enrich the literature. In this study, the data is about Ade Londok's viral words, then will be conducted further action the way he used that diction. Then, the observation was be done by the author to analyze Ade Londok's words and attempt to transcribe into the written form. It is in line with theory proposed of Keraf (2001). Futhermore, the authors analyzed the kind of diction that was used by Ade Londok. Regarding the explanation, this study purposes to figure out the kind of diction of Ade Londok's speech, to achieve the aim, the question is as follow:

1. What kind of diction that is used by Ade Londok through the viralness of promotion of Odading Mang Oleh's homemade cake?

\section{FINDINGS AND DISCUSSION}

In the study entitled Discourse Analysis of Diction Used in Ade Londok's words to persuade people to buy Mang Oleh's homemade odading cake. The authors want to immerse the deeply understanding of the usage of diction by Ade Londok. The controversial and viralness diction that is used by Ade Londok caused Mang Oleh's homemade odading cake be something interesting to explore. It was known that Ade Londok was promoting a typical Bandung cake called odading in an unusual manner. He promoted odading with mixed accents, between Sundanese and Indonesian. He also slips in a tickling rhyme, so that it makes his figure interesting to watch. "Odading Mang Oleh. Mmmm it feels like you become Iron Man. Buy Odading Mang Oleh... "said Ade in a viral video when promoting this Bandung-style cake.

\section{Abstract word}

Abstract words are the word that birth a referent in the form of concepts, rows described as difficult abstraction allusions cannot be captive by busyness feel. e.g.,: Abstract words refers to a quality ( heat, cool, good, bad, etc.), affinity ( amount, quantity, degree, etc. ), and thought ( suspicion, determination, confidence, etc.). From the words that is used by Ade Londok "Odading Mang Oleh..mmm it feels like you become an Iron Man" it can be analyzed that the words contain specifically and unusual meaning. Ade Londok used an Iron Man to describe people who eat odading home made cake. An Iron man as an abstract word because it describes thought.

2. Special word

Special words are words that advert to particular directives and concrete. Especially chat is viewing to that especially aim E. g: Yamaha, Nokia, grouper, imitator etc.

Ade Londok words refers to special object called Iron Man which described as a fictional superhero appearing in American comic books.

3. Popular word

Means rows normally victimised by all levels of society, both by the intelligentsia or to the average somebody E. g: ground disappoint, forward-moving backside etc.

The viral of words "Iron Man " used by Ade Londok refers to popular word because the words were very popular in most people and most people are very familiar with the hero called Iron Man. 


\section{Jargon}

Means technological rows or unavowed in a field of science especial in the humanities commerce, compendium of secrets, or other especially assemblies,e.g., hot potato

The word "Iron Man " used by Ade Londok refers to Jargon word because it contains a technical and secret word that influences people's thoughts.

This section presents the discussion based on the findings of the study. It is concerned about the diction that is used by Ade Londok. Diction, however, is the choice of words in speaking or speech. According to Hornby (1974), diction is the choice and use of words, style or manners of speaking and writing. Moreover, Gorys Keraf (2001) declared that there are three primary conclusions as the diction. Firstly, diction includes a sense about which word is used in conveying a thought, how to calculate the right words and use the right expressions, and the best style to use in that situation. Secondly, diction is the ability or skill in groping the right form in adaptability of situation and ethics being achieved by society and hearer/listener. Thirdly, the right and suitable word choice is only achieved by having a large numbers of memorizing vocabularies.

This study focuses on the analysis of diction used in Ade Londok's words to persuade people to buy Mang Oleh's homemade odading cake. Based on the findings in this study, it can be concluded that the words used by Ade Londok to persuade buyers contains abstract word, special word, popular word, and jargon. This is based on Keraf's theory (1984).

From the words that is used by Ade Londok "Odading Mang Oleh..mmm it feels like you become an Iron Man" it can be analyzed that the words contains specifically and unusual meaning. Ade Londok used an Iron Man to describe people who eat odading home made cake. An Iron man as an abstract word because it describes thought. Nietzsche (2006) stated abstrack is the nature of language. It uses symbols- words- to represent reality. Nietzschealso said it is important to remember that those words are not reality itself. In that fact lies both the great benefit and the great danger of language.

In relation to the character of the speakers, this can be seen based on the nature and characteristics of Ade Londok, who tend to be humorous and full of things that attract buyers to come. Further, an Iron man appears a special object described as a fictional superhero appearing in American comic books. Iron Man used by Ade Londok refers to popular words because the words were very popular in most people and most people are very familiar with the hero called Iron Man.

In addition, the words that was used by Ade Londok refers to Jargon word because it contains a technical and secret word that influence people thoughts. As its definition, Fromkin et al. (2007) emphasized that jargon is used by different professional and different groups in so extensive and so obscure in meaning. Jargon refers to the unique vocabulary used by particular group of people to facilitate communication providing a means of bonding, and exclude outsiders. So it can be use to avoid the barrier of outsiders from understanding something. It can be seen from the word "Iron Man" that made people who hear that feel like an Iron Man indeed.

\section{CONCLUSIONS}

This study used Keraf theory which aimed to know kinds of diction that was used by Ade Londok to persuade people to buy odading homemade cake. Diction that was used by Ade Londok in the word "OdadingMang Oleh. Mmmm it feels like you become Iron Man. Buy OdadingMang Oleh...contained four kinds of diction based on Keraf theory; those are abstract words, special word, popular word, and jargon. Some limitations of the study are acknowledged. First, the data collection was limited to one single caption. Further research should be devoted to larger data which could lead to more in-depth analysis. 


\section{REFERENCES}

Ary, D., Jacobs, L. C., \& Razavie, A. (2002). Introduction to research in education. New York: Wadiworth, Thomson learning.

El-Sharkawy, E. A. (2016). What is Critical Discourse Analysis (CDA)? Afif College of EducationEnglish Department, Shaqra University

Eriyanto. (2009). Analisis Wacana. Yogyakarta: LKiS.

Fairclough, N. (1995). Critical discourse analysis. London: Longman

Fairclough, N. (2003). Analysing Discourse: Textual analysis for social research. London: Routledge.

Fromkin, V. (2007) An Introduction to Language. Ninth Edition. Boston: Wadsworth.

Gee, J. P. (2014). How to do Discourse Analysis: A Toolkit ( $2^{\text {nd }}$ ed.). London: Routledge

Gee, J. P., \& Handford, M. (2012). The Routledge Handbook of Discourse Analysis. London: Routledge.

Gee, J. P. (2010). An introduction to Discourse Analysis: Theory and Method ( $3^{\text {rd }}$ ed.). London: Routledge.

Gee, J. P. (2011). Social Linguistics and Literacies: Ideology in Discourses (4 ${ }^{\text {th }}$ ed.). London: Taylor \& Francis.

Henry, F., \& Tator, C. (2002). Discourses of domination: Racial bias in the Canadian English. University of Toronto Language Press.

Hornby, A. S. (1974). Oxford Advanced Learner's Dictionary of Current English. Great Britain: Oxford University Press.

Irfariati. (2017). Diksi dalam retorika Agus Harimurti Yudhoyono sebagai calon Gubernur DKI Jakarta. Metalingua Journal, 15(1), 41-52.

Irfariati. (2013). Diksi dalam retorika Anas Urbaningrum. Madah Journal, 4(1), 11-24.

Johnstone, B. (2018). Discourse Analysis( $3^{\text {rd }}$ ed.). Blackwell.

Keraf, G.(2001). Diksi dan gaya bahasa, Jakarta: PT. Gramedia Pustaka Utama

Moleong, L. (2000). Metodologi penelitian kualitatif. Yogyakarta: Reke Sarasin.

Mulyana, D. (2001). Ilmu Komunikasi: Suatu pengantar. Bandung: PT. Remaja Rosdakarya.

Nietzsche, F. (2006). Abstractvs. Concrete. Rob_Parkinson@writingForResults.net

Paltridge, B. (2000). Making Sense of Discourse Analysis. Australia: GerdStabler.

Rosenwasser, D., \& Stephen, J. (2012). Writing Analytically (6th ed.) Wadsworth.

Widdowson, H. (2002). Language and Literature: The critical practices. Sage Journal. 